\title{
ENGLISH TEACHERS' PERCEPTION TOWARD CHARACTER ASSESMENT IN 2013 CURRICULUM: A STUDY ON JUNIOR HIGH SCHOOLS IN MANADO AND TOMOHON, NORTH SULAWESI
}

\author{
Ervita Carolina Tania, Nihta V. F. Liando, Mister Gidion Maru
}

\begin{abstract}
This research aims at finding out the perceptions of English teachers on character aspects which are not directly taugh. Yet it becomes a priority to asses basic competence. This study attempts to identify the obstacles for implementing curriculum 2013 particularly student character assessment. As a qualitative research, data are obtained through interviews. The data are taken from the schools that implement the curriculum especially six teachers who are randomly selected out of twenty teachers from each school.

The results reveal that most of the teachers perceived that aspects of the should be taught indirectly. Such perception was based upon the notion that character is not to be taught but to be practiced. Those teachers were also of the opinion that character assessment does not guarantee the positive character building. They believed that school must involve the parents and society for the success of the character education. The teachers met the problems in implementing the assessment such as time consuming, complicated assessment process, incompatiblity with big class and the lack of facility.
\end{abstract}

Keywords: perception, character assesment, english teacher, curriculum 2013

\section{INTRODUCTION}

Throughout time, societies have recognized the need to educate the coming generation of adults to pass on knowledge and skills. Recorded history from long before the present era emphasizes that education must also develop character. In school, character education must be approached comprehensively to include emotional, intellectual and moral qualities of a person or group. It must offer multiple opportunities for students to learn about, discuss and enact positive social behaviors. Student leadership and involvement are essential for character education to become a part of a student's beliefs and actions.

In Indonesia, an upraise issue nowaday in education field is Curriculum 2013, or known as K13. K13 is considered as a revision of the previous curriculum, KTSP 2004 and KTSP 
2006, which integrates competence of attitude, knowledge, and skill in comprehension. Curriculum 2013 was developed based on competences that highly necessary in conducting students to become: (1) manusia berkualitas yang mampu dan proaktif menjawab tantangan zaman yang selalu berubah; (2) manusia terdidik yang beriman dan bertakwa kepada Tuhan Yang Maha Esa, berakhlak mulia, sehat, berilmu, cakap, kreatif, mandiri; dan (3) warga negara yang demokratis dan bertanggung jawab, as stated in "Modul Pelatihan Implementasi Kurikulum 2013" (2014).

K13 has been widely applied all over the province in Academic Year 2014/2015, although some schools have started to apply it in Academic Year 2013/2014, because they are considered as model schools. However, most schools have to stop the implementation after applying it for one semester, due to some problems occurred. The models schools keep implementing the curriculum until now. One of the problems is assessment. Assessment in education is to determine importance, size, or value of it. Assessment aspects in K13 involve attitude, knowledge, and skill. Attitude refers to students' character. When knowledge and skill are directly taught, characters aspects are indirectly taught, but have to be assessed.

In Curriculum 2013, the character aspects that should be assessed are; menghargai dan menghayati ajaran agama, (spiritual aspect), jujur, disiplin, tanggung jawab, toleransi, gotong-royong, santun, percaya diri (social aspect). In Curriculum 2013, character is included as priority in Basic Competence $(K D)$, but not directly taught. In implementing Curriculum 2013, especially dealing with character values implementation in real class, teachers must include character aspects in delivering their material, as stated in "Modul Implementasi Kurikulum 2013" (2014). That is not impossible to do, but when we look at the indicators of each aspect in character value that should be assessed with such less time allocated to teach the character aspects, assessing students' character will be another problem.

Another issue with character education in school is, is it effective in preparing our next generation to perform noble character in the future? Following Kohlberg (1978) argument, moral development is the product of an interaction between child's cognitive structures and structural features of social environment, thus, if schools really want to develop character education, they must cooperate with students' social environment, because not every student lives in a supporting environment or society where good characters are practiced. Otherwise, the good character education schools have programmed will be meaningless once the student go back to his or her society, which does not support good character development.

Teachers all over the provinces in Indonesia were prepared for this curriculum in a very short time, while they have to deal with fundamental changes in Curriculum 2013 comparing with the previous ones they have been accustomed. Absolutely there will be some gaps in how teachers are positioned them-selves between the obligation to follow the rules set by Government, and to run something new for them when they were not well 
prepared. Teachers are the applicator of this curriculum. It would be better to consider the teachers' obstacles they come across in implementing the curriculum, especially dealing with character assessment, due to number of character aspects they must assess. We must not forget that numbers of students in every school are different. One teacher may be dealing with hundreds of students every day, while another may be dealing with fewer students. It can be imagined how hard it is for the teachers who deal with many students every day, and they must assess each of the character aspects provided by the curriculum.

The purposes of this study are, first, to find out teachers' perception about character aspects that are not directly taught while they are put as priority in Basic Competence. Second, to reveal the effectiveness of assessing character aspects to guarantee students' noble character in the future. Third, is to reveal the obstacles teachers must face everyday in assessing students' character in Curriculum 2013.

In conducting the study, the writer delimits her study to English teachers at SMP Negeri 1 Tomohon, SMP Negeri 7 Manado, SMP Negeri 8 Manado, in which the schools are still practising Curriculum 2013 because they are model schools, and they have been practicing this curriculum for two (2) years. The research is mainly discuss about their perspective toward students' character assessment in Curriculum 2013 context, in relation to the character aspects that are not directly taught, the effectiveness of assessing students' character aspects to guarantee students' noble character in the future, and the obstacles teachers are facing in assessing students' character.

\section{THEORETICAL BASES}

\section{Perception}

Perception leads to decision-making and action taking. At the most basic level, the decision is to act or not to act and this depends on how you develop motivation. With every action, there is always a set of alternatives from which to choose. Walgito (1981) described perception as an impression that someone gets through stimulation, organisation, and intrepretation of an object that become integrated activities. Robbins (2003) argued that perception is an impression someone gets through his or her senses, and be organized, be interpreted, and then be evaluated, in order to reveal a meaning.

The definitions above enrich each other, and it can be concluded that perception is an impression that gets from a stimolous, and has been through an integrated process in order to become a meaning.

According to Comb (2003), perception happens in one of five ways; see something with eyes, smell something with nose, hear something with ears, feel something with skin, 
taste something on tongue. According to Walgito (1981), perception happens within stages as follow:

a. Physical stage, when a stimulus received by senses.

b. Physiological stage, when the stimolus is received by senses such as seeing, hearing, tasting, sensing, smelling, and then transfered to the brain.

c. Physicological stage, is when an information received that make someone understand, realise, and evaluate an object.

d. Result stage, is when an object has been going through previous stages above, and response or impression is formed.

This research talks about perception through sense of seeing. The informations from the handout of Curriculum 2013 about the students' character aspects are read and then transferred and filtered in the brain. Those stages bring teachers into consciously aware of the stimuli, before they begin to analyze and interpret the perceived objects in order to make impressions.

The teachers' perception will be greatly influenced by many factors including their experiences, feelings, imagination, values, memories, beliefs and cultural setting. Content and degree of those influence factors will be different for everyone. Different people could perceive a same object or event very differently. The meaning they give to a stimulus will shape the choices and actions in response to it.

Every individual may produce different perception than another individual toward a single object. Every individual must also have different experiences that influence the process of perception. Therefore, perception is subjective, eventhough people are facing a same object. According to Comb (2003), there are characteristics that come within the process of perception. They are:

a. Constance: An individual perceived an object in constant, even though an object might change its characteristic.

b. Selective: Not every object that is received at the same time will be percepted. Normally, the most interesting or usefull will be perceived first.

c. The object can be perceived, organized, or evaluated differ from another individual.

According to Saks and Johns (2005), there are three components to perception:

1. The Perceiver, the person who becomes aware about something and comes to a final understanding. There are three factors that could influence his or her perceptions: experience, motivational state and finally emotional state. In different motivational or emotional states, the perceiver will react to or perceive something in different ways. 
Also in different situations, he or she might employ a "perceptual defense" where they tend to "see what they want to see".

2. The Target, is the person who is being perceived or judged. "Ambiguity or lack of information about a target leads to a greater need for interpretation and addition."

3. The Situation, which also greatly influences perceptions because different situations may call for additional information about a target.

Walgito (1990) also provided some indicators of perception, which are adapted by the researcher in this research:

1. Absorpting, in this case, a stimulation is absorbed or received through seeing, listening, sensing, smelling, and tasting. The result of absoption is impression.

2. Understanding or comprehensing, in this case, after someone gets an impression, it then be organized, be classified, be compared, and then be interpreted before it comes to an understanding or comprehension. The process of understanding is unique and fast, and sometimes influences by old impression or apperception.

3. Evaluating, in this case, after an understanding or comprehensing, comes an evaluation. Someone comparing an understanding within criteria or norms subjectively.

\section{Character Assessment in Curriculum 2013}

Developing Indonesian National Character has become the realization of "Pancasila and Pembukaan UUD 1945", based on current national issues nowadays, such as ethical values shifting, weakness in practising moral and national cultural values, and other minor behavior traits. Based on the issue mentioned above, character education is not merely to teach which is right and which is wrong, but more than that, is to invest good habit that enable students to understand (dealing with cognitive) which is right and which is wrong, to sense (dealing with affective) good virtue, and to do (dealing with psychomotor) good character traits. In other words, good character must involve moral knowing, moral sensing, and moral action. The competences above should underlie character assessment.

Sutarno (2004) described character as a view that comes with tendency to respond certain objects like things in surrounding, people, event, action, opinion, norms, and others, whether the response is in positive or in negative way. It can be concluded that character as response of one's surrounding.

In general, assessment is giving value of an object, which is seen, sensed, or observed. Sudjana (2012) explained that to state whether right or wrong, a criterion or measurement is needed. From his explanation, it can be seen that assessment is a process of giving value toward an object based on certain criteria. Furthermore, he stated that the process started with 
interpretation, and ended with judgment, in order to compare the criteria and the realization within certain context.

Curriculum sees character as tendency to respond something or object. It is also seen as expression of values that one has. However, character can be directed into desirable behavior or action. Therefore, character competencies within curriculum try to manifest the values someone believes into action in his or her daily life.

Character assessment in Curriculum 2013 is a set of activities that designed to measure students' character as a result of a learning program. It is also an application of a standard or decision toward character. The function of character assessment is as part of reflection of comprehension and progression that student make individually.

In relation to character assessment, the main goal is to train students to act good character. It is not an easy thing to do, therefore, Curriculum 2013 involves authentic assessment to create some learning activities that contain characters, and in the same way measure students' character.

Authentic assessment is a process of evaluation uses to measure achievement, motivation, and students' character in its relevance to teaching and learning process, as stated in "Modul Implementasi Kurikulum 2013" (2014). Wiggins (1989) described authentic assessment as task given to students that reflects priority and challenge that are discovered within learning activities such as researching, writing, revising, discussing an article and giving oral analysis toward an object, a collaborating with other students through debate and so on.

Applying authentic assessment for character in Curriculum 2013 is done by observing students' activities in school during teaching and learning process, of how they behave during lesson, of how they treat their friends, and of how they act. However, we must not forget that character education is also highly influenced by school vision to create good character to students. Teachers' role to build, to lead, and to develop students' character is necessary too.

To optimize students' character development, three aspects that play vital role are family, school, and society. Each of these aspects contributes in educating and forming students' character. Therefore, school and family must choose and create conducive atmosphere.

Based on Andersen (1981), character covers three skills at once, Cognitive, affective, and psychomotor. Cognitive deals with students' understanding about concept and indicator of character. For example, when talking about honesty, students must understand the definition and classification of honesty.

Affective skill deals with students' emotional relationship toward character. This skill covers three aspects, which are accepting, supporting, and commitment in doing good character. Accepting refers to whether a student agrees or not toward good character. For 
example, does a student agree if honesty is a good character? Supporting deals with students' response toward character that others show. For example, does a student like if someone treats him or her honesty? Commitment in doing good character deals with students' will to have and to perform good character in every occasion. For example, once a student accept and support honesty as a good character trait, he or she will commit to act honesty.

Therefore, the method given to students in order to lead them to a characterized people must consider rationally touching cognitive skill, intuitively to touch affective skill, and motorist to touch psychomotor skill.

Character assessment must cover those three skills mentioned above. Teacher must prepare indicator and assessment instrument to measure cognitive, affective, and psychomotor. Assessing cognitive skill can be done as assessing knowledge skill, such as multiple choice or essay. Assessing students' affective skill can be done by using character scale, self-assessment, pier assessment, journal, and observation. Assessing psychomotor skill can be done by have students to act out a character trait, role-play, stimulation, or other techniques.

Based on the three skills of character mentioned above, and character aspects that are provided by Curriculum 2013, before conducting character assessment, teachers need to consider some indicators, and the indicators can be seen in "Modul Pelatihan Kurikulum 2013" (2014), as stated below:

a. Cognitive skill:

1. Understand the definitions of appreciating and practicing religious doctrine, respect, honesty, discipline, being responsible, tolerance, cooperation, being polite, and self-confidence.

2. Understand the spessification of appreciating and practicing religious doctrine, respect, and honesty, discipline, being responsible, tolerance, cooperation, being polite, and self-confidence.

b. Affective skill

1. Agree if appreciating and practicing religious doctrine, respect, honesty, discipline, being responsible, tolerance, cooperation, being polite, and self-confidence are good character traits.

2. Agree when someone show them how to appreciate and practice religious doctrine, and treat them with respect, honesty, discipline, being responsible, tolerance, cooperation, being polite, and self-confidence.

3. Agree to perform appreciating and practicing religious doctrine, respect, honesty, discipline, being responsible, tolerance, cooperation, being polite, and selfconfidence in every occasion. 
4. Commit to perform appreciating and practicing religious doctrine, respect, honesty, discipline, being responsible, tolerance, cooperation, being polite, and self-confidence in every occasion.

c. Psychomotor skill

1. Have the students commit to perform appreciating and practicing religious doctrine, respect, honesty, discipline, being responsible, tolerance, cooperation, being polite, and self-confidence in every occasion.

2. Have the students perform appreciating and practicing religious doctrine, respect, honesty, discipline, being responsible, tolerance, cooperation, being polite, and self-confidence in every occasion.

As stated in "Modul Pelatihan Implementasi Kurikulum 2013" (2014), educators assess character through observation, self assessment, peer assessment and journal. Every subject teacher should do assessment process, and the report is given to homeroom teacher, who will present it as student's report. In the beginning of each subject, teacher informs students about the character competencies that are going to be assessed, which are spiritual competence and social competence.

After that, teacher develops assessment instruments in relates to the subject he or she is teaching. Teacher explains the assessment criteria for each character aspects that are going to be assessed. Teacher processes the result of assessment refers to scoring guidance and assessment criteria that have been set. At the end of each semester, every score from the beginning to the end of semester must be described in graphic, and the final score is set from the average score. After all the stages above are done, the score is given to homeroom teacher as student's final report.

By the end of each semester, each subject teacher must report the result of character assessment whether it is spiritual or social in integrative. The report written in qualitative form, and must be described. The criteria of the written form for score are; sangat baik $(S B)$, baik (B), cukup $(C)$, kurang $(K)$. However, teachers cannot give C score for students' character, because $\mathrm{C}$ is considered that the student is immoral. The score must contain description of students' character competence achievement from every subject course.

\section{Methodology}

Descriptive design occupies in this research to obtain general overview of the subject discussed. Descriptive design is a scientific method, which involves observing and describing the behavior of a subject without influencing it in any way. Many scientific disciplines, especially social science and psychology, use this method to obtain a general overview of the subject. 
The population is Junior High Schools in Tomohon and Manado city that are still practicing Curriculum 2013. Six English teachers taken as representative, two teachers from every school, that selected randomly. The researcher focuses on English teachers in Junior High Schools, which the schools are still practicing Curriculum 2013, such as SMP Negeri 1 Tomohon, SMP Negeri 7 Manado, SMP Negeri 8 Manado.

This research uses structured interview to collect the data. An interview is a conversation between two or more people where questions asked by the interviewer to elicit facts or statements from the interviewee. An interview is a standard part of qualitative research.

In the process of making sense of qualitative data, the writer adopts the framework developed by Miles and Huberman (1994) to describe the major phases of data analysis, which are data reduction, data display, and conclusion drawing and verification.

\section{Finding and Discussion}

\section{Finding}

This study is conducted during April and March 2016 at three Junior High Schools in Tomohon and Manado city. The schools are chosen because they are still going on with Curriculum 2013 implementation. Six English teachers agree to be participants in the study. Two samples are taken from every school randomly. The participants are coded as sample 1 (S1), sample 2 (S2), sample 3 (S3), sample 4 (S4), sample 5 (S5), and sample 6 (S6).

All samples are female teachers, with age range above thirty (30) years old. They have various teaching experience, from nine to twenty eight years. The samples are teaching various grades, from seventh to ninth grade. Five samples were graduated from English Education Department of Manado State University, and one sample was graduated from Post Graduate Program of English Education Program, Manado State University.

From the interview, the researcher finds that most participants perceived that character aspects can be taught indirectly. The character aspects can be integrated within subject course, with no need to add certain subject. However, most of them are sure that assessing character aspects would not guarantee students' noble character in the future. When the question goes into the obstacles they are facing in assessing students' character aspects, most participants found that assessing students' character aspects are time consuming, complicated process, not suitable for big class, and lack of facilities.

\section{Discussion}

Integrating character aspects within subject course is indeed in compliance to Curriculum 2013 context. However, if we look back to the theory of character education by Kohlberg (1978), the researcher argues that cognitive structures cannot be merely given by integrating them within subject course. In this case, the cognitive structures of nine character aspects that the curriculum provides. 
Indeed, "Modul Implementasi Kurikulum 2013" says that teacher may choose which character aspects that are going to be introduced, in relation to the topic currently discussed. Yet, for English subject, Curriculum 2013 provides four times forty (4 x 40) minutes each week, which are distributed into two meetings each week. The question arise is, is the time allocation enough for the students to know the character aspect, to understand the definition of the aspect, and to be given example of the character aspect. After that, teachers have to teach course material.

For example, an English teacher has to deliver a topic about self-introduction, and the given time allocation is 4 x 40 minutes, which are distributed within two meetings. The character aspects that relate to the topic are politeness and self-confidence. The teacher has to inform the students about the topic at hand first, and then inform the students about politeness and self-confidence related to the topic. After that, the teacher has to explain the definition of politeness and self-confidence before checking the students' understanding about the definition, and show example of politeness and self-confidence. As the final step, the teacher must encourage students to practice the example given in their daily lives. After all of the requirements above are done, then the teacher teaches about the topic.

From the illustration above, the writer perceives that character aspects must be introduced directly within certain subject. Character assessment in Curriculum 2013 involves authentic assessment, which is used to measure students' cognitive, affective, and psychomotor aspects. When it deals with cognitive aspect, the instruments to measure students' ability is conducted based on students' knowledge. Therefore, character aspects should be directly taught to students. However, when it comes to affective, it can be integrated within teacher's subject course.

All of the steps above have to be done in order to the success of character education, as stated by Rest (1986), that learners must have direct input in the setting agenda. From Rest's theory, the researcher concludes that students must be exposed to the input, in this case aspects of character, so students would know exactly about the character, whether it is good or bad, and finally build their own will to act the character.

Dealing with the effectiveness of assessing students' character aspects, in agreement with the theories involved by the researcher, most of the participants are sure that assessing students' character is not effective to guarantee students' noble character in the future. Matthews and Riley (1995) determined that effective ethics education is grounded in community. They ensure failure if ethics taught without using a community context to illustrate, nurture, and support ethical development. Without grounding ethics within particular community and cultural context of a learner, ethics remain abstract, outside the scope of experiences of the learner, and ultimately irrelevant.

Therefore, parents' role is important in supporting school program of character 
education. School must have enough information about students' background before they register to the school, in order to give appropriate treatment to student. Schools also need parents' cooperation to follow up students' activities outside the school.

Environment also contributes in forming students' character, especially neighborhood. We cannot deny that students are also social individual, who need to know other people, and to interact with them. Often, when children grow in a neighborhood in which there are many mischievous youngsters, the children show tendency to follow the attitude. On the contrary, students cannot choose which neighborhood to live in, because of their parents' economical state. However, children may choose which attitude to be followed, when family realize the importance of character building, and plant good character earlier.

Furthermore, Lockwood (1993) argued that this character assessment only well performed on assignments such as worksheet or activities booklets. When students know that their character comprehensions are going to be assessed, they give positive responses as they are expected to, and do the otherwise when teachers do not notice. Whether we realize it or not, this habit only directs students into hypocrite demeanor. Therefore, in developing character education, schools must involve families and societies to support the program.

Dealing with the the obstacles teachers are facing in assessing students' character in Curriculum 2013 context, in accordance to the theories involves by the researcher, most samples found some obstacles with the character evaluation process, such as time consuming, complicated process, not suitable for big class, and lack of facilities that school provide.

Lickona (2007) stated that character values must be elaborated into representative indicators, so the achievement can be measured. Talking about character means talking about values someone possesses. Definitely, the values assessed are good values. In assessing character value that someone has, often the assessor perception is influenced by subjective perception. Therefore, to avoid subjective perception, indicators of assessment are needed. Thus, indicators must be provided to determine whether a character trait is good or not. For instance, if a teacher wants to assess students' politeness, he or she would not ask the students to act politely without some standard of measurement. When a character aspect elaborated into representative indicators, some possible standards must be measured. Surely, teacher must allocate more times in measuring one character aspect.

In this research, most samples were also found that the process of assessing character assessment is complicated. Sudjana (2012) argued that the process of assessment started from interpretation, and ended with judgment. The researcher would say that making representative indicators is part of interpretation, in which teacher makes objective interpretation toward a student based on the indicators. After interprets a student's character, then the judgment is made, in which teacher determine the score, based on the score range. All of the steps above must be followed to gain valid score. 
In Indonesia, many schools accommodate more than thirty-five students in one class. With such number of students in one class, teachers are definitely experience difficulty to control the class, and to evaluate each student's character. Furthermore, when the schools do not provide adequate facilities to facilitate teachers in assessing students, such as assessment instruments and suitable application to make students' report, the teachers certainly need extra times to assess students' character.

The researcher is aware that assessing students' character is time consuming and complicating process, but the writer understands that every process of assessment must be followed to gain valid scores.

\section{Conclusion}

Most English teachers perceived that teaching character aspects could be done through indirect teaching. The reasons underlying the perception mostly because the character aspects can be shown instead of taught. Their perceptions are against the theories the writer adapts, that introducing character aspects to students involved cognitive structure of the students. Basically, when dealing with cognitive structure, students need to be introduced to each definition of character aspects by delivering the material in direct teaching. But when dealing with students' affective structure, the character aspects can be shown to students in integrative subject course.

Most English teachers perceived that assessing students' character aspects is not effective to guarantee students' noble character in the future. The reason underlying the perception is because the school's efforts in forming students' character must involved families' and societies' role. Basically, one's character is highly influences by his or her environment. So, environment, in this case family and society must also work together to support the curriculum's goal to improve students' noble character.

Most samples found some obstacles relate to character assessment process. According to them, they need more times to do it, the process is complicated, not suitable for big class, and lack of facilities provided. Basically, when assessing students' character, there are number of considerations dealing with assessment indicators and criteria. In doing the assessment, some processes must be followed as well. That is why assessing students' character takes more time. Surely if a school accommodates more students than it should be in one class, assessing each character aspects will be harder for teachers. When talking about facilities, in reality there are many schools especially at suburbs that could not provide adequate facilities to support teaching and learning process. 


\section{REFERENCES}

Andersen, Lorin. W. (1981). Assessing Affective Characteristic in the Schools. Boston: Allyn and Bacon.

Combs DR ${ }^{1}$. (2003). The Role of Subclinical Paranoia on Social Perception and Behavior, Schizophrenic Res. Jul 1;69(1):93-104.

Kohlberg, L. (1978). Revisions in the Theory and Practice of Moral Development. In W. Damon (1981) (Ed.). New Directions for Child Development: Moral Development. New York: Wiley.

Lickona, Schaps and Lewis. (2007). Journal of Research in Character Education, p.33. http://books.google.co.id/books?id.

Lockwood, A. L. (1993). A Letter to Character Educators. Educational Leadership, 51, $72-$ 75.

Matthews, B. E. \& Riley, C. K. (1995). Teaching and Evaluating Outdoor Ethics Programs. Vienna, VA: National Wildlife Federation. (ERIC Document Reproduction Service No. ED 401 097).

Miles, Matthew B. and Huberman, A. Michael. (1994). An Expanded Sourcebook Qualitative Data Analysis, SAGE Publications.

MODUL PELATIHAN IMPLEMENTASI KURIKULUM 2013, Kementrian Pendidikan dan Kebudayaan 2014.

Rest, J. R. (1986). Moral development: Advances in Research and Theory. New York: Praeger.

Robbins. (2003). Organizational Behavior: Perception and IndividualDecisionMaking. 13th Edition Chapter 5.

Saks, Alan \& Gary Johns. (2005). Perception, Attribution, and Judgment of Others. Organizational Behaviour: Understanding and Managing Life at Work. Vol. 7. Toronto: Pearson Prentice Hall.

Sudjana, Nana. (2012). Penilaian Hasil Proses Belajar Mengajar. Cetakan XVII. Bandung: PT Remaja Rosdakarya.

Sutarno, Daniel Nuhamara. (2004). Di Dalam Dunia, Tetapi Tidak Dari Dunia: Pemikiran Teologis Tentang Pergumulan Gereja Dalam Masyarakat Indonesia Yang Majemuk. BPK Gunung Mulia.

Walgito, Bimo. (1981). Pengantar Psikologi Umum. Yogyakarta: Penerbit ANDI.

Wiggins, G. (1989). “A True Test: Toward More Authentic and Equitable Assessment." Phi Delta Kappan, 70. 